\title{
DISTRIBUTION REVISED- FIFTEEN YEARS OF CHANGES IN THE INVASION OF A FRESHWATER FISH, PSEUDORASBORA PARVA (TEMMINCK AND SCHLEGEL, 1846) IN TURKEY
} Gülnaz ÖZCAN * and Ali Serhan TARKAN **

* İskenderun Technical University, Faculty of Marine Sciences and Technology İskenderun, Hatay, Turkey, TR-31200, gulnazozcan@gmail.com

** Muğla Sıtkı Koçman University, Faculty of Fisheries, Kötekli, Muğla, Turkey, TR-48000/University of Łódź, Faculty of Biology and Environmental Protection, Department of Ecology and Vertebrate Zoology, 12/16 Banacha Street, Łódź, Poland, PL-90-237, serhantarkan@gmail.com

DOI: 10.2478/trser-2019-0013

KEYWORDS: Non-native, topmouth gudgeon, introduction, distribution, Anatolia.

\section{ABSTRACT}

The aim of the present paper is to revise the distribution range of the invasive freshwater fish species, topmouth gudgeon Pseudorasbora parva (Temminck and Schlegel, 1846) in Turkey, based on the literature review. After the first report of the species from the Meriç River in Thrace (European part of Turkey) in 1982, it has spread across the country mainly through human-mediated accidental introductions. The species has now been reported from 66 water bodies in total. Besides the introduction pathways, we also present chronological distribution pattern of the species. This information is useful especially for conservation endemic ichthyofauna due to the negative impact of Pseudorasbora parva, particularly through introducing an emerging infectious eukaryotic intracellular pathogen on the fungal-animal boundary, Sphaerothecum destruens Arkush et al., 2003.

ZUSAMMENFASSUNG: Eine überprüfte Verbreitung- fünfzehn Jahre von Veränderungen betreffend die Invasion des Süßwasserfischs Pseudorasbora parva (Temminck und Schlegel, 1846) in der Türkei.

Ziel der vorliegenden Arbeit ist es, auf Grund der Durchsicht neuerer Fachliteratur das Verbreitungsgebiet des Süßwasserfischs Pseudorasbora parva (Temminck und Schlegel, 1846) in der Türkei zu revidieren. Nach einer ersten Meldung der Art im Meriç-Fluss in Thrakien (europäischer Teil der Türkei) im Jahr 1982 hat sich die Art im Land vorwiegend über zufälliges Einschleppen durch den Menschen verbreitet und wurde gegenwärtig insgesamt aus 66 Gewässern gemeldet. Es werden auch die Einschleppungswege und die chronologischen Verbreitungsmodelle der Art dargestellt. Diese Information wird als nützlich erachtet, vor allem im Hinblick auf den Erhalt der endemischen Fischfauna, wegen des negativen Einflusses von Pseudorasbora parva durch das Einschleppen eines eukaryotischen, intrazellularen ansteckenden Pathogens an der Pilz-Tier Grenze Sphaerothecum destruens Arkush et al., 2003.

REZUMAT: Distribuţie revizuită- cinsprezece ani de schimbări în invazia unui peşte de apă dulce, Pseudorasbora parva (Temminck şi Schlegel, 1846) în Turcia.

Scopul prezentei lucrări este revizuirea ariei de distribuţie a speciei invazive de apă dulce, Pseudorasbora parva (Temminck şi Schlegel, 1846) în Turcia, pe baza revizuirii literaturii. După o primă raportare a speciei în râul Meriç din Tracia (partea europeană a Turciei) în 1982, sa răspândit în ţară în principal datorită introducerilor antropice accidentale şi a fost raportată dintr-un număr total de 66 de bazine de apă. Sunt de asemenea prezentate căi de introducere şi modele cronologice de distribuţie a specie. Această informaţie se crede că este utilă în special pentru conservarea ihtiofaunei endemice. Efectul negativ a murgoiului bălţat, este reprezentat în particular prin introducerea unui patogen eucariot intracelular infecţios emergent la graniţa fungi-animale, Sphaerothecum destruens Arkush et al., 2003. 


\section{INTRODUCTION}

In general, freshwater ecosystems and its endemic specific fauna are adversely affected by introduction of non-native species, pollution and drought (Marr et al., 2013). Non-native fish species are usually introduced into freshwater ecosystems through transportation, aquaculture and biological control along with fish stocking, fisheries and pet trade (Allan and Flecker, 1993; Maitland, 1995; Ruesink, 2005; Özcan, 2008; Tarkan et al., 2015). In the case of being invasive, non-native fish species have great potential to impact native biota both economically and ecologically (Cucherousset and Olden, 2011).

Turkey has a rich freshwater fish biodiversity with high number of endemic species (Tarkan et al., 2015). In total, 377 species have been reported so far; the majority belongs to the Cyprinidae family (Çiçek et al., 2015). In Turkey, there are approximately 157 endemics (Çiçek et al., 2015) and 30 introduced freshwater fish species being overall establishment success over 60\% (Tarkan et al., 2015). One successfully non-indigenous fish species is Pseudorasbora parva (Temminck and Schlegel, 1846), which is an invasive species of the European fish fauna that influence native and endemic fishes by generating damages (Curtean-Bănăduc and Bănăduc, 2007-2008; DIAS, 2017; GISD, 2017; NISD, 2017) including in pond fish farming as a strong competitor (Csorbai et al., 2014) and healthy carrier of a deadly pathogen Sphaerothecum destruens Arkush et al., 2003 (Gozlan et al., 2005).

Pseudorasbora parva was originally discovered in Nagasaki, Japan and they are also naturally distributed in China and Siberia (Berg, 1949). This species was recorded in Europe in the 1960s; they were possibly introduced through the movement of Chinese carps for fish farming (Gozlan et al., 2010) and the species was reported in Turkey for the first time in 1982 from Meriç River (Thrace - European part of Turkey) (Erk'akan, 1984), then from Aksu River (Anatolia - Asian part of Turkey) in 1994 (Wildekamp et al., 1997). Ekmekçi and Kırankaya (2006) reviewed the distribution of the species in Turkey and reported seven new locations for the species. Since then, several new locations have been recorded for the species except for Eastern part of the country (e.g. Uğurlu and Polat, 2007; İlhan and Balık, 2008; Şaş1 and Berber, 2013; Çınar et al., 2013; Bakaç et al., 2017; Gül et al., 2017; Karakuş et al., 2017; Küçük et al., 2018). Since distribution pattern of Pseudorasbora parva has not properly been reviewed despite its presence in Turkish inlands for almost four decades and available information on the distribution range is obsolete, we aimed to present current distribution and introduction pathways of the species in Turkey.

\section{MATERIAL AND METHODS}

A literature review was performed in Web of Science, and supplemented by Google Scholar, starting with the species name ("Pseudorasbora parva" and "topmouth gudgeon") and country of interest ("Turkey") as well as complimentary words ("new”, "record”, "locality”, “occurrence”, “distribution”, "spread”, "range” and their combinations). Also, available journal archives, reports and grey literature were reviewed. All location reports were tabulated and visualized with a table and figure, respectively by enumerating them chronologically. The introduction rate of Pseudorasbora parva was calculated as the average number of new locations introduced per decade after Ribeiro et al. (2009). 


\section{RESULTS AND DISCUSSION}

For Turkish freshwater bodies, Pseudorasbora parva is considered one of the most ecologically damaging species that is rapidly spreading and become established (Ercan et al., 2015; Tarkan et al., 2015). Our near-comprehensive literature screening presented that Pseudorasbora parva is widely distributed in Turkey, particularly in the regions located in western part of the studied country; Aegean, Mediterranean and Marmara regions (Fig. 1).

The average rate of introduction to Turkey of Pseudorasbora parva since the first introduction of the species in early 1980s up to the date is 1.7 per decade. For the period 1990-2020 and 2000-2020 it is 2.2 and 2.9 species per decade (Fig. 2). Although this rate is now almost the same (2.9 vs. 2.8) for the last two decades (i.e. 2000-2010 and 2010-2020), it is likely that the latter would be higher with potential new location reports in next two years until 2020 (Fig. 2). This considerable increase could apparently be attributable to lack of ichthyofaunal surveys and the species' misidentification especially before 2000s where the former is still true for the eastern part of the country (Fig. 1). Indeed, there is a relatively long time (i.e. 12 years) and distance (approximately $900 \mathrm{~km}$ ) between first (Erk'akan, 1984) and second record (Küçük and İkiz, 2004) of the species but after 2000s, new reports of the species has remarkably increased, mostly from the regions located between first two reported locations (Tab. 1; Fig. 1). The fourth report of the species was in late 1990s from a basin (Sakarya Basin), which is located in between those locations (Ekmekçi, 2000).

Based on the pattern of Pseudorasbora parva introductions since the first report in Turkey, it is likely that the actual distribution of the species in its introduced range reflects a "stepping-stone" type of invasion model, which is characterized as "further introduction from initial one" (Gozlan et al., 2010). This is because the major vectors for the introduction of Pseudorasbora parva to Turkey have been indicated as government authorized aquaculture and stocking programmes to establish and support cage aquaculture, and commercial fisheries (Tarkan et al., 2015). Hence, the accidental transfer and release of Pseudorasbora parva within the translocations of native cyprinids (mainly common carp Cyprinus carpio) for aquaculture characterize the primary pathway of Pseudorasbora parva introduction into its expanded range in Turkey. Our review of location reports of the species supports this suggestion as it has been reported from distant locations in different times, i.e. does not follow a regular distribution pattern (Tab. 1; Fig. 1). Indeed, second record of Pseudorasbora parva in Anatolia after its first report of in Thrace strongly suggests that the expansion of the species by natural ways is not likely, as this freshwater gudgeon species cannot pass two salt water barriers (i.e. İstanbul and Çanakkale straits), which separates European and Asian parts of Turkey. Recent findings of the species in a remote location (i.e. Gökçeada Island) have strengthened this contention (Bakaç et al., 2017). 


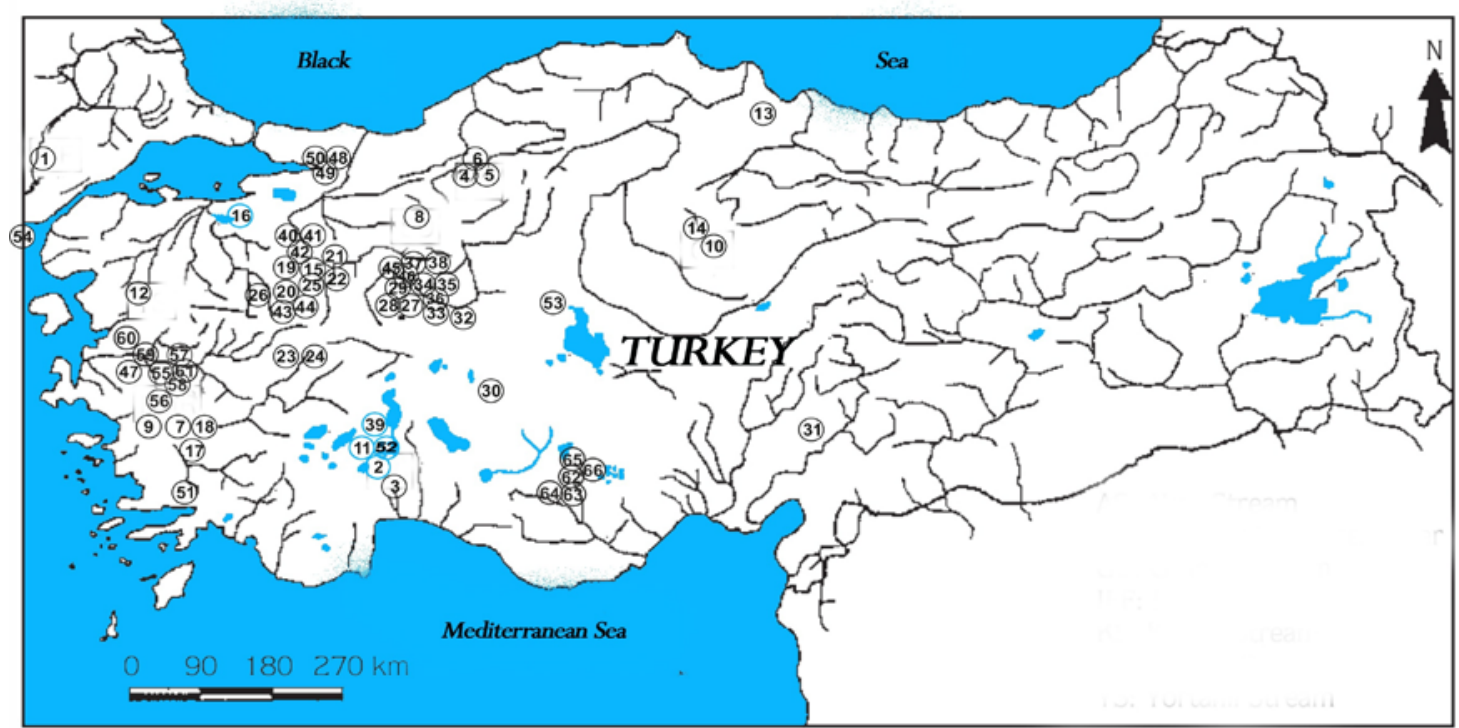

Figure 1: Updated distribution map of Pseudorasbora parva in Turkish inlands by location:

1. Meriç River; 2. Karacaören I-II reservoirs; 3. Aksu River; 4. Kirmir Stream; 5. Kirmir

Stream; 6. Kirmir Stream; 7. Topçam Reservoir; 8. Sarıyar Reservoir; 9. Dipsiz-Çine Stream; 10. Gelingülü Reservoir 11. Gölcük Lake 12. Yortanlı Stream 13. Bekdiğin Pond

14. Gelingülü Reservoir; 15. Ağaçköy Stream, Felek Stream and Enne Reservoir; 16. Uluabat

Lake; 17. Kemer Reservoir; 18. Topçam Reservoir; 19. Sekiören Pond; 20. Pazarlar Pond;

21. Doğluşah Pond; 22. Söğüt Reservoir; 23. Altınbaş Pond; 24. Göğem Pond; 25. Enne

Reservoir; 26. Kayaboğazı Reservoir; 27. Çatören Reservoir; 28. Kunduzlar Reservoir;

29. Erenköy Pond; 30. Meyil Lake; 31. Evri Stream; 32. Günyüzü II Pond; 33. Koçaş Pond; 34. Mercan Pond; 35. Bahçeçik Pond; 36. Kaymaz Reservoir; 37. Yenice Reservoir;

38. Gökçekaya Reservoir; 39. Eğirdir Lake; 40. Küçükelmalı Pond; 41. Kızıldamlar Reservoir;

42. Dodurga Reservoir; 43. Dumlupınar Pond; 44. Çavdarhisar Pond; 45. Porsuk River;

46. Akın Creek; 47. Marmara Lake; 48. Bayraktar Reservoir; 49. Kirazoğlu Reservoir;

50. Davuldere Reservoir; 51. Ula Reservoir; 52. Onaç Reservoir; 53. Mogan Lake;

54. Gökçeada Reservoir; 55. Demirköprü Reservoir; 56. Afşar Reservoir; 57. Gördes Stream;

58. Marmara Lake; 59. Gediz River; 60. Demirci Stream; 61. Kemerdamları Drainage Channel;

62. Gödet Creek; 63. Gödet Reservoir; 64. Deliçay Reservoir; 65. İbrala Reservoir;

66. Ayranc1 Reservoir; for details see table 1.

According to Hanel et al. (2011), Pseudorasbora parva can establish abundant populations in stagnant bodies of water compared to running waters. This is in line with our review showing that out of 66 water bodies, 50 were stagnant water (lake, reservoir and pond) and only 16 were running water (creek, stream and river) (Tab. 1). Also, reviewed resources confirmed that it become established more abundantly in still waters. High phenotypic plasticity in fitness related traits such as growth, early maturity, fecundity, reproductive behaviour (paternal care) and the ability to cope with novel pathogens has predisposed the Pseudorasbora parva to be a strong invader (Gozlan et al., 2010). Recently, Pseudorasbora parva in Turkey has been shown to grow better than both native and non-native populations (Akbaş et al., 2015). Further, Pseudorasbora parva was considered as a serious threat to native and endemic fish species in several water bodies of Turkey that have high biodiversity richness (Ekmekçi and Kırankaya, 2006; Özcan, 2008; Polat et al., 2011). 
Notably, the most compelling issue regarding the invasion of Pseudorasbora parva is that it is a healthy carrier of a rosettte agent Sphareothecum destruens, a generalist pathogen on the animal-fungal boundary (Gozlan et al., 2005). After the experimental evidence of the pathogen in Pseudorasbora parva (Gozlan et al., 2005), first field evidence was provided from Turkey (Sarıçay River, Milas, SE Turkey) (Ercan et al., 2015), which also proved its introduction via Pseudorasbora parva to sea bass farms and linking the pathogen to severe declines in threatened European endemic freshwater fishes (i.e. 80\% to $90 \%$ mortalities).

Table 1: Chronological list of reported locations of Pseudorasbora parva in Turkish inlands.

\begin{tabular}{|c|c|c|c|}
\hline No. & References & Location & Report Date \\
\hline 1. & Erk’akan, 1984 & $\begin{array}{l}\text { Meric River-Üpsala/ } \\
\text { Edirne }\end{array}$ & 16 September 1982 \\
\hline 2. & Küçük and İkiz, 2004 & $\begin{array}{l}\text { Karacaören I-II } \\
\text { Reservoirs/Aksu } \\
\text { River/Isparta-Burdur }\end{array}$ & $\begin{array}{l}\text { November 1994-October } \\
\text { 1996/September 2002- } \\
\text { August } 2003\end{array}$ \\
\hline 3. & Wildekamp et al., 1997 & $\begin{array}{l}\text { Aksu River/ } \\
\text { Antalya }\end{array}$ & 29-30 July 1996 \\
\hline 4. & Ekmekçi, 2000 & $\begin{array}{l}\text { Sakarya Kirmir } \\
\text { Stream }\end{array}$ & 1999 \\
\hline 5. & Ekmekçi, 2000 & Kirmir Stream & 1998 \\
\hline 6. & $\begin{array}{l}\text { Ekmekçi and Kırankaya, } \\
2006\end{array}$ & Kirmir Stream & January 1998 \\
\hline 7. & Şaşı and Balık, 2003 & $\begin{array}{l}\text { Topçam Reservoir/ } \\
\text { Aydın }\end{array}$ & June 1999-June 2000 \\
\hline 8. & $\begin{array}{l}\text { Ekmekçi and Kırankaya, } \\
2006\end{array}$ & Sarıyar Reservoir & November 1999 \\
\hline 9. & Barlas and Dirican, 2004 & $\begin{array}{l}\text { Dipsiz-Çine Stream/ } \\
\text { Aydın }\end{array}$ & $\begin{array}{l}\text { November } 1999 \text { and } \\
\text { February } 2001\end{array}$ \\
\hline 10. & $\begin{array}{l}\text { Ekmekçi and Kırankaya, } \\
2006\end{array}$ & $\begin{array}{l}\text { Gelingülü Reservior, } \\
\text { Kızllırmak/Yozgat }\end{array}$ & June/2002-December 2004 \\
\hline 11. & Yeğen et al., 2015 & $\begin{array}{l}\text { Gölçük Lake/ } \\
\text { Isparta }\end{array}$ & 17 May 2003 \\
\hline 12. & $\begin{array}{l}\text { Ekmekçi and Kırankaya, } \\
2006\end{array}$ & $\begin{array}{l}\text { Yortanlı Stream/Bakırçay/ } \\
\text { İzmir }\end{array}$ & - \\
\hline 13. & Uğurlu and Polat, 2007 & $\begin{array}{l}\text { Bekdiğin Pond/ } \\
\text { Samsun }\end{array}$ & June 2003-September 2005 \\
\hline 14. & Yalçın-Özdilek et al., 2013 & $\begin{array}{l}\text { Gelingüllü Reservoir/ } \\
\text { Yozgat }\end{array}$ & $\begin{array}{l}\text { Summer } 2003 \text { and } \\
\text { Summer } 2005 \\
\end{array}$ \\
\hline 15. & İlhan and Balık, 2008 & $\begin{array}{l}\text { Ağaçköy Stream - Felek } \\
\text { Stream, Enne } \\
\text { Reservoir/Kütahya }\end{array}$ & Summer 2004 and 2005 \\
\hline 16. & Çınar et al., 2013 & $\begin{array}{l}\text { Uluabat Lake } \\
\text { (Apolyont)/Bursa }\end{array}$ & $\begin{array}{l}\text { January } 2006 \text { and } \\
\text { December } 2006\end{array}$ \\
\hline
\end{tabular}


Table 1 (continued): Chronological list of reported locations of Pseudorasbora parva in Turkish inlands.

\begin{tabular}{|c|c|c|c|}
\hline 17. & Şaşı and Berber, 2013 & $\begin{array}{l}\text { Kemer Reservoir/ } \\
\text { Aydın }\end{array}$ & $\begin{array}{l}\text { April } 2007 \text { to } \\
\text { February } 2008\end{array}$ \\
\hline 18. & Şaşı and Berber, 2013 & $\begin{array}{l}\text { Topçam Reservoir/ } \\
\text { Aydın }\end{array}$ & $\begin{array}{l}\text { April } 2007 \text { to } \\
\text { February } 2008\end{array}$ \\
\hline 19. & Yeğen et al., 2015 & $\begin{array}{l}\text { Sekiören Pond/ } \\
\text { Kütahya }\end{array}$ & 03 May 2007 \\
\hline 20. & Yeğen et al., 2015 & $\begin{array}{l}\text { Pazarlar Pond/ } \\
\text { Kütahya }\end{array}$ & 22 May 2007 \\
\hline 21. & Yeğen et al., 2015 & $\begin{array}{l}\text { Doğluşah Pond/ } \\
\text { Kütahya }\end{array}$ & 24 May 2007 \\
\hline 22. & Yeğen et al., 2015 & $\begin{array}{l}\text { Söğüt Reservoir/ } \\
\text { Kütahya }\end{array}$ & 24 May 2007 \\
\hline 23. & Yeğen et al., 2015 & $\begin{array}{l}\text { Altınbaş Pond/ } \\
\text { Uşak }\end{array}$ & 14 June 2007 \\
\hline 24. & Yeğen et al., 2015 & $\begin{array}{l}\text { Göğem Pond/ } \\
\text { Uşak }\end{array}$ & 14 June 2007 \\
\hline 25. & Yeğen et al., 2015 & $\begin{array}{l}\text { Enne Reservoir/ } \\
\text { Kütahya }\end{array}$ & 28 August 2007 \\
\hline 26. & Yeğen et al., 2015 & $\begin{array}{l}\text { Kayaboğazı Reservoir/ } \\
\text { Kütahya }\end{array}$ & 30 August 2007 \\
\hline 27. & Yeğen et al., 2015 & $\begin{array}{l}\text { Çatören Reservoir/ } \\
\text { Eskişehir }\end{array}$ & 24 October 2008 \\
\hline 28. & Yeğen et al., 2015 & $\begin{array}{l}\text { Kunduzlar Reservoir/ } \\
\text { Eskişehir }\end{array}$ & 24 October 2008 \\
\hline 29. & Yeğen et al., 2015 & $\begin{array}{l}\text { Erenköy Pond/ } \\
\text { Eskişehir }\end{array}$ & 01 October 2008 \\
\hline 30. & Özuluğ et al., 2013 & $\begin{array}{l}\text { Meyil Lake } \\
\text { (Konya) }\end{array}$ & 2008 \\
\hline 31. & Özuluğ et al., 2013 & $\begin{array}{l}\text { Evri Stream } \\
\text { (Kahramanmaraş) }\end{array}$ & 2008 \\
\hline 32. & Yeğen et al., 2015 & $\begin{array}{l}\text { Günyüzü II Pond/ } \\
\text { Eskişehir }\end{array}$ & 28 April 2009 \\
\hline 33. & Yeğen et al., 2015 & $\begin{array}{l}\text { Koçaş II Pond/ } \\
\text { Eskişehir }\end{array}$ & 28 April 2009 \\
\hline 34. & Yeğen et al., 2015 & $\begin{array}{l}\text { Mercan Pond/ } \\
\text { Eskişehir }\end{array}$ & 29 April 2009 \\
\hline 35. & Yeğen et al., 2015 & $\begin{array}{l}\text { Bahçeçik Pond/ } \\
\text { Eskişehir }\end{array}$ & 29 April 2009 \\
\hline 36. & Yeğen et al., 2015 & $\begin{array}{l}\text { Kaymaz Reservoir/ } \\
\text { Eskişehir }\end{array}$ & 30 April 2009 \\
\hline 37. & Yeğen et al., 2015 & $\begin{array}{l}\text { Yenice Reservoir/ } \\
\text { Eskişehir }\end{array}$ & 26 May 2009 \\
\hline
\end{tabular}


Table 1 (continued): Chronological list of reported locations of Pseudorasbora parva in Turkish inlands.

\begin{tabular}{|c|c|c|c|}
\hline 38. & Yeğen et al., 2015 & $\begin{array}{l}\text { Gökçekaya Reservoir/ } \\
\text { Eskişehir }\end{array}$ & 27 May 2009 \\
\hline 39. & Yağc1 et al., 2014 & $\begin{array}{l}\text { Eğirdir Lake/ } \\
\text { Isparta }\end{array}$ & March 2010 and June 2011 \\
\hline 40. & Yeğen et al., 2015 & $\begin{array}{l}\text { Küçükelmalı Pond/ } \\
\text { Bilecik }\end{array}$ & 06 May 2010 \\
\hline 41. & Yeğen et al., 2015 & $\begin{array}{l}\text { K1zıldamlar Reservoir/ } \\
\text { Bilecik }\end{array}$ & 06 July 2010 \\
\hline 42. & Yeğen et al., 2015 & $\begin{array}{l}\text { Dodurga Reservoir/ } \\
\text { Bilecik }\end{array}$ & 18 August 2010 \\
\hline 43. & Yeğen et al., 2015 & $\begin{array}{l}\text { Dumlupınar Pond/ } \\
\text { Kütahya }\end{array}$ & 19 Auguist 2010 \\
\hline 44. & Yeğen et al., 2015 & $\begin{array}{l}\text { Çavdarhisar Reservoir/ } \\
\text { Kütahya }\end{array}$ & 19 August 2010 \\
\hline 45. & Yeğen et al., 2015 & $\begin{array}{l}\text { Porsuk River/ } \\
\text { Eskişehir }\end{array}$ & 16 August 2011 \\
\hline 46. & Yeğen et al., 2015 & $\begin{array}{l}\text { Akın Creek/ } \\
\text { Eskișehir }\end{array}$ & 13 September 2011 \\
\hline 47. & İlhan and Sarı, 2013 & $\begin{array}{l}\text { Marmara Lake/ } \\
\text { Manisa }\end{array}$ & March 2012-February 2013 \\
\hline 48. & Keskin et al., 2013 & $\begin{array}{l}\text { Bayraktar Reservoir/ } \\
\text {-İzmit }\end{array}$ & 2012 \\
\hline 49. & Keskin et al., 2013 & $\begin{array}{l}\text { Kirazoglu Reservoir/ } \\
\text {-İzmit }\end{array}$ & 2012 \\
\hline 50. & Keskin et al., 2013 & $\begin{array}{l}\text { Davuldere Reservoir/ } \\
\text {-İzmit }\end{array}$ & 2012 \\
\hline 51. & Keskin et al., 2013 & $\begin{array}{l}\text { Ula Reservoir/ } \\
\text {-Muğla }\end{array}$ & 2012 \\
\hline 52. & Yeğen et al., 2015 & $\begin{array}{l}\text { Onaç Reservoir/ } \\
\text { Burdur }\end{array}$ & 02 October 2013 \\
\hline 53. & Gül et al., 2017 & $\begin{array}{l}\text { Mogan Lake/ } \\
\text { Ankara }\end{array}$ & January-December 2014 \\
\hline 54. & Bakaç et al., 2017 & $\begin{array}{l}\text { Gökçeada Reservoir/ } \\
\text { Çanakkale }\end{array}$ & 08 June 2016 \\
\hline 55. & Karakuş et al., 2017 & $\begin{array}{l}\text { Demirköprü } \\
\text { Reservoir/Manisa }\end{array}$ & March-August 2017 \\
\hline 56. & Karakuş et al., 2017 & $\begin{array}{l}\text { Afşar Reservoir/ } \\
\text { Manisa }\end{array}$ & March-August 2017 \\
\hline 57. & Karakuş et al., 2017 & $\begin{array}{l}\text { Gördes Stream/ } \\
\text { Manisa }\end{array}$ & March-August 2017 \\
\hline
\end{tabular}


Table 1 (continued): Chronological list of reported locations of Pseudorasbora parva in Turkish inlands.

\begin{tabular}{|c|l|l|l|}
\hline 58. & Karakuş et al., 2017 & $\begin{array}{l}\text { Marmara Lake/ } \\
\text { Manisa }\end{array}$ & March-August 2017 \\
\hline 59. & Karakuş et al., 2017 & $\begin{array}{l}\text { Gediz River/ } \\
\text { Manisa }\end{array}$ & March-August 2017 \\
\hline 60. & Karakuş et al., 2017 & $\begin{array}{l}\text { Demirci Stream/ } \\
\text { Manisa }\end{array}$ & March-August 2017 \\
\hline 61. & Karakuş et al., 2017 & $\begin{array}{l}\text { Kemerdamları Drainage } \\
\text { Channel/Manisa }\end{array}$ & March-August 2017 \\
\hline 62. & Küçük et al., 2018 & $\begin{array}{l}\text { Gödet Creek/ } \\
\text { Karaman }\end{array}$ & 2015-2017 \\
\hline 63. & Küçük et al., 2018 & $\begin{array}{l}\text { Gödet Reservoir/ } \\
\text { Karaman }\end{array}$ & 2015-2017 \\
\hline 64. & Küu̧ük et al., 2018 & $\begin{array}{l}\text { Deliçay Reservoir/ } \\
\text { Karaman }\end{array}$ & $2015-2017$ \\
\hline 65. & Küçük et al., 2018 & $\begin{array}{l}\text { İbrala Reservoir/ } \\
\text { Karaman }\end{array}$ & $2015-2017$ \\
\hline 66. & Küçük et al., 2018 & $\begin{array}{l}\text { Ayranc1 Reservoir/ } \\
\text { Karaman }\end{array}$ & $2015-2017$ \\
\hline
\end{tabular}

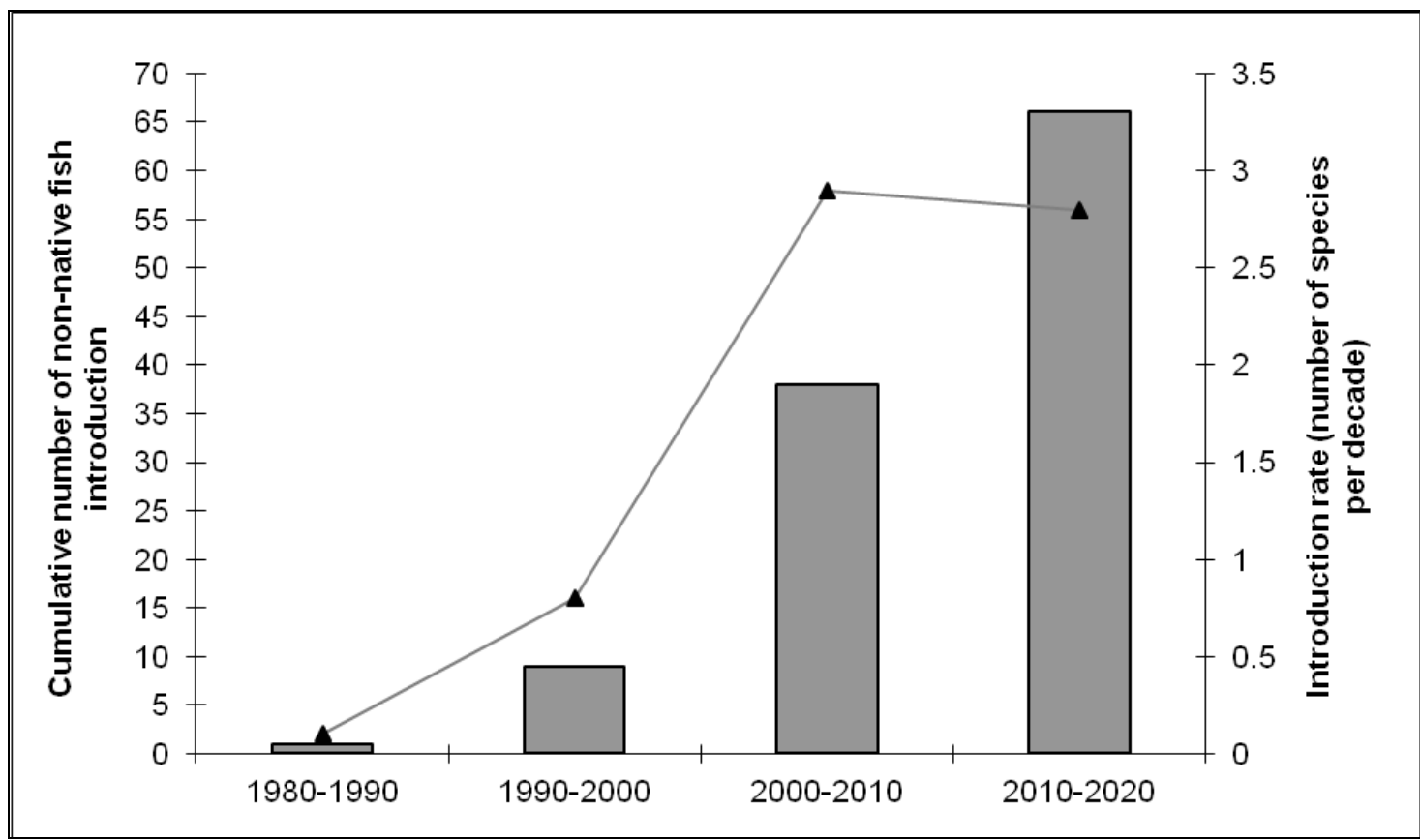

Figure 2: Temporal pattern of introduction of Pseudorasbora parva into Turkish watersheds.

Cumulative number of the species introduction (left axis)

and the rate of the species introduction per decade (right axis) is presented. 


\section{CONCLUSIONS}

Overall, our near comprehensive review points out rapid and wide spread distribution of Pseudorasbora parva in Turkey and suggests that it would increasingly continue to spread in the future. It is most probable that the number of new records of the species in Turkey will increase with more frequent ichthyofaunal researches especially in the eastern part of Turkey.

To this end, Pseudorasbora parva introductions and related infectious diseases should constantly be monitored and necessary management actions with robust risk assessments should follow given rich native and endemic freshwater biodiversity in Turkey. 


\section{ACKNOWLEDGEMENTS}

The authors would like to thank the Prof. Dr. Tahir Özcan for their help including some critical advice. 


\section{REFERENCES}

1. Akbaş F., Tarkan A. S., Gaygusuz Ö., Dorak Z. and Aydın H., 2015 - Türkiye’de bulunan yabancı bir Tatlısu balığı, çakıl balığı Pseudorasbora parva'nın yaşam döngüsü özelliklerinin doğal ve yerel olmayan populasyonlarıyla karşılaştırmalı olarak incelenmesi: farklılıklar kolonizasyon başarısını açıklayabilir mi? 2th Symposium on Fish Introduction and Reservoir Management, May 20-22, Eğirdir/Isparta-Turkey. (in Turkish)

2. Allan J. D. and Flecker A. S., 1993 - Biodiversity conservation in running waters, BioScience, 43, 1, 32-43.

3. Arkush K. D., Mendoza L., Adkison M. A. and Hedrick R. P., 2003 - Observations on the life stages of Sphaerothecum destruens n. g., n. sp., a mesomycetozoean fish pathogen formerly referred to as the rosette agent, Journal of Eukaryot Microbiology, 50, 6, 430-8.

4. Bakaç İ., Yalçın-Özdilek Ş. and Ekmekçi F. G., 2017 - İstilacı balık türü Pseudorasbora parva (Temminck and Schlegel, 1846) Çakıl balığı'nın Gökçeada (Çanakkale)'dan ilk kaydı, Ege Journal of Fisheries and Aquatic Sciences, 34, 4, 459-462. (in Turkish)

5. Barlas M. and Dirican S., 2004 - The fish fauna of the Dipsiz-Çine (Muğla-Aydın) stream, Gazi University Journal of Science, 17, 3, 35-48.

6. Berg L. S., 1949 - Ryby presnykh vod SSSR i sopredel'nykh stran, Moscow and Leningrad, Akademiya Nauk SSSR, 496. (in Russian)

7. Çiçek E., Birecikligil S. S. and Fricke R., 2015 - Freshwater fishes of Turkey: A revised and updated annotated checklist, Biharean Biologist, 9, 2, 141-157.

8. Çınar Ş., Küçükkara R., Balık İ., Çubuk H., Ceylan M., Erol K. G., Yeğen V. and Bulut C., 2013 - Uluabat (Apolyont) Gölü’ndeki balık faunasının tespiti, tür kompozisyonu ve ticari avcılığın türlere göre dağılımı, Journal of FisheriesSciences.com, 7, 4, 309-316 (in Turkish).

9. Csorbai B., Pereszlényi A., Kovács R., Urbányi B. and Horváth L., 2014 - The habitat use and Selectivity by topmouth gudgeon (Pseudorasbora parva), Acta Zoologica Academiae Scientiarum Hungaricae, 60, 4, 389-400.

10. Cucherousset J. and Olden J. D., 2011 - Ecological impacts of non-native freshwater fishes, Fisheries, 36, 215-230.

11. Curtean-Bănăduc A. and Bănăduc D., 2007-2008 - Trophic elements regarding the nonindigenous Pseudorasbora parva (Schlegel) 1842 fish species spreading success - Olt River basin, a case study, Romanian Journal of Biology, 52-53, Edit. Academiei Române, 33-52.

12. DIAS, 2017 - Database on Introductions of Aquatic Species.

13. GISD, 2017 - Global Invasive Species Database.

14. Gozlan R. E., St-Hilaire S., Feist S. W., Martin P. and Kent M. L., 2005 - Disease threats to European fish, Nature, 435, 1045-1046.

15. Gozlan R. E., Andreou D., Asaeda T., Beyer K., Bouhadad R., Burnard D., Caiola N., Cakic P., Djikanovic V., Esmaeili H. R., Falka I., Golicher D., Harka A., Jeney G., Kováč V., Musil J., Povz M., Nocita A., Virbickas T., Wolter C., Tarkan A. S., Tricarico E., Trichkova T., Verreycken H., Witkowski A., Zhang C., Zweimueller I. and Britton J. R., 2010 - Pan-continental invasion of Pseudorasbora parva: towards a better understand fish invasions, Fish and Fisheries, 11, 315-340.

16. Gül A., Benzer S., Saylar Ö., Gül G. and Yılmaz M., 2017 - Mogan Gölü balık faunası, Journal of Balikesir University Institute of Science and Technology, 19, 1, 91-103. (in Turkish)

17. Ekmekçi F. G., 2000 - Türkiye'de Sulak Alanlarda Balıkçılığı Etkileyen çevresel sorunlar, TSE Standad, 462, 62-69. (in Turkish)

18. Ekmekçi F. G. and Kırankaya Ş. G., 2006 - Distribution of an invasive fish species, Pseudorasbora parva in Turkey, Turkish Journal of Zoology, 30, 329-334.

19. Ercan D., Andreou D., Sana S., Öntaş C., Baba E., Top N., Karakuş U., Tarkan A. S. and Gozlan R. E., 2015 - Evidence of threat to European economy and biodiversity following introduction of an alien pathogen on the fungal-animal boundary, Emerging Microbes and Infections, 4, e52.

20. Erk’akan F., 1984 - Trakya Bölgesi’nden Türkiye için yeni kayıt olan bir balık türü Pseudorasbora parva (Cyprinidae), Doğa Bilimleri Dergisi, A2, 8.3, 350-351. (in Turkish) 
21. Hanel L., Plesník J., Andreska J., Lusk S., Novák J. and Plíštil J., 2011 - Alien Fishes in European Waters, Bulletin Lampetra, VII, 148-185.

22. İlhan A. and Balık S., 2008 - Batı Karadeniz Bölgesi içsularının balık faunası, Ege University Journal of Fisheries and Aquatic Sciences, 25, 1, 75-82. (in Turkish)

23. İlhan A. and Sarı H. M., 2013 - Marmara Gölü balık faunası ve balıkçılık faaliyetleri, Ege University Journal of Fisheries and Aquatic Sciences, 30, 4, 187-191. (in Turkish)

24. Karakuş U., Top-Karakuş N. and Tarkan A. S., 2017 - Distribution and new records of nonnative Pseudorasbora parva in Manisa Province, Turkey, II, Workshop on Invasive Species: Global meeting on invasion ecology, September, Bodrum, Turkey, 67, 27-29.

25. Keskin E., Ağdamar S. and Tarkan A. S., 2013 - DNA barcoding common non-native freshwater fish species in Turkey: Low genetic diversity but high population structuring, Mitochondrial DNA, 24, 3, 276-287.

26. Küçük F. and İkiz R., 2004 - Antalya Körfezi’ne dökülen akarsuların balık faunası, E.U. Journal of Fisheries and Aquatic Sciences, 21, 3-4, 287-294. (in Turkish)

27. Küçük F., Güçlü S. S. and Gülle İ., 2018 - New habitat records for invasive Atherina boyeri, Carassius gibelio and Pseudorasbora parva (Teleostei) from Turkey, International Symposium Ecology, 19-23 June, Kastamonu, Turkey, 335.

28. Maitland P. S., 1995 - The conservation of freshwater fish: Past and present experience, Biological Conservation, 72, 259-270.

29. Marr S. M., Olden J. D., Leprieur F., Arismendi I., Caleta M., Morgan D. L., Nocita A., Šanda R., Tarkan A. S. and García-Berthou E., 2013 - A global assessment of freshwater fish introductions in Mediterranean-climate regions, Hydrobiologia, 719, 317-329.

30. NISD, 2017 - Non Indigenous Species Database.

31. Özcan G., 2008 - Büyük Menderes Nehir Havzası'ndaki egzotik balık türleri ve etkileri, Türk Bilimsel Derlemeler Dergisi, 1, 2, 23-25. (in Turkish)

32. Özuluğ M., Saç G. and Gaygusuz Ö., 2013 - İstilacı özellikteki Gambusia holbrooki, Carassius gibelio ve Pseudorasbora parva (Teleostei) türleri için Türkiye’den yeni yayılım alanları, Ístanbul University Journal of Fisheries and Aquatic Sciences, 28, 1-22. (in Turkish)

33. Polat N., Zengin M. and Gümüş A., 2011 - İstilacı balık türleri ve hayat stratejileri, Karadeniz Fen Bilimleri Dergisi, 1, 4, 63-86. (in Turkish)

34. Ribeiro F., Collares-Pereira M. J. and Moyle P. B., 2009 - Non-native fish in the fresh waters of Portugal, Azores and Madeira Islands: a growing threat to aquatic biodiversity, Fisheries Management and Ecology, 16, 255-264.

35. Ruesink J. L., 2005 - Global analysis of factors affecting the outcome of freshwater fish introductions, Conservation Biology, 19, 1883-1893.

36. Şaşı H. and Balık S., 2003 - The distribution of three exotic fishes in Anatolia, Turkish Journal of Zoology, 27, 319-322.

37. Şaşı H. and Berber S., 2013 - The indigenous and invasive fishes in two main reservoirs in the southwestern Anatolia, Research Journal/Cuadernos de Investigación, 5, 1, 97-101.

38. Tarkan A. S., Marr S. M. and Ekmekçi F. G., 2015 - Non-native and translocated freshwater fish species in Turkey, FISHMED Fishes in Mediterranean Environments, 2015, 003, 28.

39. Uğurlu S. and Polat N., 2007 - Exotic fish species inhabiting in freshwater sources within the province of Samsun, Journal of Fisheries Sciences, 1, 3, 139-151.

40. Wildekamp R. H., Van-Neer W., Küçük F. and Ünlüsayın M., 1997 - First record of the gobionid fish Pseudorasbora parva from the Asiatic part of Turkey, Journal of Fish Biology, 51, 858-861.

41. Yalçın-Özdilek Ş., Kırankaya Ş. G. and Ekmekçi F. G., 2013 - Feeding ecology of the Topmouth gudgeon Pseudorasbora parva (Temmnick and Schlegel, 1846) in the Gelingüllü Reservoir, Turkey, Turkish Journal of Fisheries and Aquatic Sciences, 13, 87-94.

42. Yeğen V., Uysal R., Yağcı A., Cesur M., Çetinkaya S., Bilgin F., Bostan H. and Yağcı M., 2015 New records for ditribution of invasive Topmouth gudgeon (Temmnick and Schlegel, 1846) in Anatolia, Journal of Limnology and Freshwater Fisheries Research, 1, 1, 57-61. 